\title{
ANALISIS KEBIJ AKAN HUKUM PIDANA TERHADAP DELIK PERBUATAN TIDAK MENYENANGKAN
}

\author{
Indriana Dwi Mutiara Sari ${ }^{1}$, Handias Gitalistya ${ }^{2}$, Anggita Doramia Lumbanraja3* \\ 1Program Studi Magister Ilmu Hukum, Fakultas Hukum, Universitas Diponegoro \\ 2,3Fakultas Hukum, Universitas Diponegoro \\ anggitalumbanraja@live.undip.ac.id
}

\begin{abstract}
Objectionable Acts stipulated in the Indonesian Criminal Code (KUHP) contains elements of coercion and violence. It is increasingly used as a legal basis for prosecution in cases of humiliation or defamation. However, the implementation of the law from this article is often regarded as haatzaai artiekelen, because to explain the notion of objectionable acts is highly subjective depending on each of individual. This article discusses criminal law policy regarding current offenses (ius constitutum) and in the future (ius constituendum) by using a normative juridical approach and descriptive research specifications. The Constitutional Court Decision has reduced the criminal law policy regarding the offense of objectionable acts currently stipulated in KUHP, the phrase on its content because it cannot be measured definitely which actions are included in the criminal act so that it can create opportunities for arbitrariness both from prosecutor and law enforcement authorities. The objectionable act has not been explicitly regulated in the Criminal Code Bill (RUU KUHP). So for the sake of legal certainty, it is necessary to improve the criminal law policy regarding the objectionable acts that need to be accommodated in RUU KUHP.
\end{abstract}

\section{Keywords: Objectionable Acts; The Constitutional Court Decision.}

\begin{abstract}
ABSTRAK
Delik Perbuatan Tidak Menyenangkan diatur dalam KUHP, mengandung unsur adanya paksaan dan kekerasan. Pasal KUHP mengenai delik ini sering dijadikan sebagai dasar hukum penuntutan pada kasus penghinaan atau pencemaran nama baik. Namun seiring waktu dalam penerapan hukum dari pasal ini sering dianggap sebagai pasal karet, karena untuk menjelaskan pengertian perbuatan tidak menyenangkan sangatlah subjektif tergantung dari masing-masing individunya. Artikel ini membahas tentang kebijakan hukum pidana mengenai delik perbuatan tidak menyenangkan saat ini (ius constitutum) dan dimasa mendatang (ius constituendum) dengan menggunakan metode pendekatan yuridis normatif dan spesifikasi penelitian berupa deskriptif analisis. Kebijakan hukum pidana mengenai delik perbuatan tidak menyenangkan yang saat ini telah diatur dalam KUHP telah mengalami pengurangan frasa pada isi pasalnya berdasarkan Putusan Mahkamah Konstitusi karena tidak bisa diukur secara pasti perbuatan apa saja yang masuk dalam delik tersebut, sehingga dapat menimbulkan peluang kesewenang-wenangan baik dari pelapor maupun pihak penegak hukum. Putusan Mahkamah Konstitusi ini tidak serta merta membuat perubahan besar pada kebijakan hukum pidana mengenai delik perbuatan tidak menyenangkan. Hal ini terlihat dari belum diaturnya delik ini secara khusus dalam RUU KUHP. Maka demi kepastian hukum, perlu adanya perbaikan pada kebijakan hukum pidana mengenai delik perbuatan tidak menyenangkan yang perlu diakomodir di dalam RUU KUHP.
\end{abstract}

Kata Kunci: Perbuatan Tidak Menyenangkan; Putusan Mahkamah Konstitusi.

\footnotetext{
${ }^{*}$ Corresponding Author
} 


\section{A. PENDAHULUAN}

Tindak kejahatan yang terjadi saat ini menunjukkan semakin tidak berperikemanusiaan. Kejahatan sebagai masalah fenomena sosial tetap dipengaruhi oleh berbagai aspek kehidupan dalam masyarakat, seperti politik, ekonomi, sosial, budaya serta hal-hal yang berhubungan dengan upaya pertahanan dan keamanan negara. Perkembangan kejahatan sesuai dengan berkembangnya ilmu pengetahuan dan teknologi. Perbuatan tidak menyenangkan melalui internet sering kali terjadi seperti mengirimkan pesan atau komen-komen yang mengandung kebencian melalui blog, email atau yahoo messenger, mengirimkan sms menyeramkan ke ponsel seseorang, membuat postingan dalam blog ditujukan untuk melecehkan atau menghina seseorang, meretas email seseorang dan mengirimkan email kepada orang lain dengan menggunakan identitas email tersebut, mengunggah foto atau video pribadi seseorang tanpa sepengetahuan pemilik.

Tindak pidana di atas selain dituntut berdasarkan Undang-Undang Informasi Transaksi Elektronik (ITE), juga menyelipkan Pasal 335 dalam sangkaannya. Delik Pasal 335 ini merupakan tindak pidana umum dan menjadi multi tafsir karena semua hal dapat dimasukkan dalam perbuatan tidak menyenangkan. Seperti yang kita ketahui, tidak ada tindak pidana yang menyenangkan, namun tidak semua perbuatan yang tidak menyenangkan termasuk sebagai tindak pidana. Penghapusan frasa "Perbuatan Tidak Menyenangkan" dalam Pasal 335
KUHP diajukan Oei Alimin Sukamto Wijaya yang merasa telah dirugikan oleh delik tersebut. Putusannya telah dibacakan Ketua Mahkamah Konstitusi Hamdan Zoelva bersama hakim Mahkamah Konstitusi lainnya dalam sidang PPU, 15 Januari 2015. Dalam pertimbangannya, Mahkamah Konstitusi menghapus frasa tersebut karena perbuatan tidak menyenangkan sebagaimana diatur dalam Pasal 335 KUHP tidak mengikat hukum. Perbuatan tidak menyenangkan tidak bisa diukur, sehingga dapat menimbulkan peluang kesewenangwenangan yang dilakukan pelapor, penyidik, dan jaksa penuntut umum (Natamenggala, Raharjo, \& Gustiniati, 2018).

Perbuatan tidak menyenangkan tersebut dimaksud Pasal 335 ayat (1) KUHP dalam implementasinya dianggap sebagai pasal karet, karena untuk menjelaskan pengertian perbuatan tidak menyenangkan sangatlah subjektif tergantung dari masing-masing individunya sehingga oleh Mahkamah Konstitusi mengeluarkan Putusan Nomor:1/Puu-Xi/2013 tentang frasa perbuatan tidak menyenangkan, sehingga dalam Pasal 335 ayat (1) KUHP frasa perbuatan tidak menyenangkan dihapus dan Pasal 335 ayat (1) butir 1 KUHP dapat diterapkan ketika memenuhi unsur dengan ancaman atau kekerasan saja (Natamenggala, Raharjo, \& Gustiniati, 2018).

Perbuatan tidak menyenangkan telah diteliti dan dibahas dalam beberapa hasil penelitian sebelumnya. Dimas Indra Swadana (Swadana, Triyoso, \& Istiqomah, 2014) membahas mengenai 
implikasi yuridis dari penghapusan frasa "sesuatu perbuatan lain maupun perlakuan yang tak menyenangkan" pada pasal 355 KUHP ayat (1) butir ke-1 oleh Putusan Mahkamah Konstitusi, dikarenakan rumusan tersebut tidak dapat diukur secara objektif dan menimbulkan ketidakpastian hukum serta ketidakadilan. Muhammad Alriezki Natamenggala (Natamenggala, 2018) memperkuat penelitian dari Swadana. Natamenggala menyatakan bahwa penghapusan frasa "perbuatan tidak menyenangkan" merupakan tindakan yang sangat efektif karena membatasi penggunaan Pasal 335 ayat (1) KUHP sehingga tidak bisa disalahgunakan. Kajian yang hampir serupa juga diteliti oleh Harry $A$ Tuhumury (Tuhumury, 2015), namun dari sisi yang berbeda. Tuhumury menemukan bahwa dampak dari penghapusan frasa "perbuatan tidak menyenangkan" dari Pasal 335 ayat (1) KUHP mengakibatkan seseorang yang merasa dirugikan dengan adanya delik perbuatan tidak menyenangkan tidak dapat lagi diproses karena tidak ada dasar hukumnya (berdasarkan asas legalitas).

Perbuatan Tidak menyenangkan telah banyak diulas oleh para pakar dari dunia internasional, diantaranya Donald P. Haider-Markel (HaiderMarkel, 1998) yang membahas tentang kebijakan pidana mengenai perbuatan tidak menyenangkan dan bagaimana upaya implementasinya. Pada kajian penelitiannya ditemukan bahwa hal ini masih sangat dipengaruhi oleh faktor politik dari negara bagian (Amerika Serikat). Sedangkan Jeanne C. Cogan (Cogan, 2002) membahas mengenai sejarah kebijakan pidana perbuatan tidak menyenangkan, di mana kebijakan ini ditujukan untuk upaya preventif.

Artikel ini membahas bagaimana kebijakan hukum pidana mengenai delik perbuatan tidak menyenangkan saat ini dan dimasa datang.

\section{B. PEMBAHASAN}

1. Kebijakan Pidana mengenai Delik Perbuatan Tidak Menyenangkan dalam KUHP Saat Ini

Pengertian tentang tindak pidana dalam Kitab Undang-undang Hukum Pidana (KUHP) dikenal dengan istilah straftbaar feit dan dalam kepustakaan tentang hukum pidana sering mempergunakan istilah delict yang berasal dari bahasa latin delictum (Hamzah, 2008). Perbuatan pidana atau delik ialah perbuatan yang dilarang oleh aturan hukum dan barangsiapa yang melanggar larangan tersebut dikenakan sanksi pidana (Soeharto, 1991).

Unsur-unsur tindak pidana menurut (Moeljatno, 1987) terdiri dari perbuatan (manusia), yang memenuhi rumusan dalam undang-undang (syarat formil), bersifat melawan hukum (syarat materiil). Adapun macam - macam delik terdiri dari delik Kejahatan dan Pelanggaran, delik Dolus dan Culpa, delik Commissionis dan delik Ommisionis, delik Formil dan delik Materiil, delik Biasa dan delik Berkualifikasi, delik Murni dan delik Aduan serta delik Selesai dan delik Berlanjut.

Rumusan Pasal 335 ayat (1) KUHP mensyaratkan adanya pemenuhan atas dua unsur yakni "memakai kekerasan" atau "ancaman kekerasan. Melihat rumusan bagian inti delik (delicts 
bestanddelen), maka kita dapat melihat bahwa tindak pidana tersebut berupa pelaku (barang siapa), bentuk perbuatannya adalah memaksa, menyuruh orang untuk melakukan / tidak melakukan sesuatu, sehingga orang itu melakukan/atau tidak melakukan sesuatu yang berlawanan dengan kehendaknya, objeknya adalah orang, dilakukan secara melawan hukum.

Perbuatan tidak menyenangkan ini diatur dalam Bab XVIII tentang Kejahatan Terhadap Kemerdekaan Orang, dan Pasal 335 KUHP ini lebih merincikan tentang perbuatan tidak menyenangkan. Dalam peristiwa ini biasanya delik tidak menyenangkan ini baru dapat di adili atau diproses ketika adanya pengaduan dari seseorang yang merasa dirugikan.

Kebijakan hukum pidana tidak dapat dipisahkan dari sistem hukum pidana. Hal ini sesuai dengan apa yang dikatakan oleh Marc Ancel bahwa tiap masyarakat yang terorganisir memiliki system hukum pidana yang terdiri dari peraturan-peraturan hukum pidana dan sanksinya, suatu aturan hukum pidana dan suatu tata cara pelaksanaan pidana (Arief, 2005).

Implikasi yuridis dari perubahan pasal 335 KUHP ayat (1) butir ke-1 tentang perbuatan tidak menyenangkan oleh Mahkamah Konstitusi berdasarkan putusan Nomor: 1/PUUXI/ 2013 tentang Penghapusan Frase Perbuatan yang Tidak Menyenangkan dilatar belakangi karena di dalam Pasal 335 KUHP ada unsur "perbuatan tidak menyenangkan". Unsur perbuatan tidak menyenangkan inilah yang membuat pasal ini fleksibel sehingga bisa digunakan untuk menjerat semua tindak pidana. Pembuatnya dapat ditahan berdasarkan Pasal 21 ayat (4) butir b Kitab Undangundang Hukum Acara Pidana (KUHAP). Pasal 335 KUH Pidana dapat dipergunakan untuk menuntut hampir semua perbuatan, sehingga praktisi hukum ada yang menyebut dengan istilah pasal karet ini rumusannya berbunyi: Diancam dengan pidana penjara paling lama satu tahun atau denda paling banyak tiga ratus rupiah:

"Ke-1:barangsiapa secara melawan hukum memaksa orang lain supaya melakukan atau membiarkan sesuatu, dengan memakai kekerasan, sesuatu perbuatan lain maupun perlakuan yang tak menyenangkan, atau dengan memakai ancaman kekerasan, sesuatu perbuatan lain maupun perlakuan yang tak menyenangkan, baik terhadap orang itu sendiri atau orang lain. Ke-2:barangsiapa memaksa orang lain supaya melakukan, tidak melakukan atau membiarkan sesuatu dengan ancaman pencemaran atau pencemaran tertulis".

Dalam hal diterangkan ke-2, kejahatan hanya dituntut atas pengaduan orang yang terkena. (KUHP, 1981)

Pasal 335 ayat (1) KUHP mensyaratkan adanya pemenuhan atas dua unsur yakni "memakai kekerasan" atau "ancaman kekerasan".

Sebagaimana telah disebutkan diatas, mengapa masalah perbuatan yang tidak menyenangkan tersebut dimasukkan dalam KUHP yaitu menyangkut kemerdekaan orang, juga dapat dilihat dari nilai filsafat hukum yang terkandung didalamnya dapat di tafsirkan ialah agar jangan terjadi perbuatan yang balas membalas atau 
perbuatan main hakim sendiri 5 (eigenrechting) antara pelaku dengan korban, hukum positif menciptakan cara membuat keseimbangan yaitu untuk menetralisir perasaan yang tidak enak tersebut, perlu campur tangan institusi penengah yaitu peradilan agar pihak yang lemah terlindungi, dan pihak yang kuat disadarkan (Kantjai, 2016).

Apabila mengacu pada Kamus Besar Bahasa Indonesia yang paling dekat mendefinisikan persekusi adalah Pasal 335 ayat (1) butir 1 Kitab Undang-Undang Hukum Pidana (KUHP) yang menyatakan bahwa: 46 "Barangsiapa secara melawan hukum memaksa orang lain supaya melakukan, tidak melakukan atau membiarkan sesuatu dengan memakai kekerasan atau dengan memakai ancaman kekerasan baik terhadap orang itu sendiri maupun orang lain". Berdasarkan pernyataan diatas bahwa Pasal 335 KUHP sangat berkaitan dengan definisi persekusi yang terdapat dalam Kamus Besar Bahasa Indonesia (KBBI) bahwa persekusi merupakan tindakan sewenangwenang/menganiaya dan perbuatan tersebut merupakan perbuatan melawan hukum. Dalam pasal 335 KUHP terdapat unsur secara melawan hukum, memaksa, supaya melakukan, tidak melakukan atau membiarkan sesuatu, dan dengan memakai kekerasan (Aulia, 2018).

Pasal 335 ayat (1) ke 1 KUHPidana, sepanjang menyangkut unsur "perbuatan lain" dan unsur "perbuatan yang tidak menyenangkan" merupakan unsur-unsur yang tidak memberikan kepastian hukum. Unsur "perbuatan lain" merupakan unsur yang tidak pasti sebab unsur ini hanya menunjuk bahwa perbuatan itu bukan merupakan perbuatan kekerasan, tetapi tidak menyebut rincian perbuatan apa yang sebenarnya dilarang. Terlebih lagi unsur "perlakuan yang tidak menyenangkan" yang oleh para disebut memiliki cakupan yang agak kabur dan amat luas, sehingga menjadi ketentuan penampung untuk banyak perbuatan yang tidak dapat dituntut berdasarkan pasal-pasal penggunaan kekerasan lainnya. Rumusan yang agak kabur dan amat luas seperti ini, jelas tidak bersesuaian dengan aspek lex certa dari asas legalitas, dengan kata lain unsur "perlakuan yang tidak menyenangkan" itu bertentangan dengan aspek lex certa dari asas legalitas. Pasal KUHPidana Belanda yang menjadi pedoman penyusunan Pasal 335 KUHPidana, sebagaimana dikatakan oleh Wirjono Prodjodikoro (Prodjodikoro, 1981) tidak memiliki unsur "perlakuan yang tidak menyenangkan". Unsur ini hanya ada dalam KUHPidana Indonesia (dahulu Wetboek van Strafrecht voor Nederlands Indie). Dengan demikian, baik unsur "perbuatan lain" maupun unsur "perlakuan yang tidak menyenangkan" merupakan unsur-unsur yang tidak bersesuaian atau bertentangan dengan aspek lex certa dari asas legalitas. Dua unsur tersebut seharusnya dihapuskan dari Pasal 335 ayat (1) ke 1 KUHPidana, ataupun dari pasal sejenis dalam penyusunan Kitab Undang-Undang Hukum Pidana Nasional yang akan datang (Kantjai, 2016).

Pada kasus yang terjadi oleh Oei Alimin Sukamto Wijaya, dimana Oei Alimin Sukamto Wijaya terlibat perkelahian di Hotel Meritus, pada 5 Agustus 
Jurnal Pembangunan Hukum Indonesia

Volume 1, Nomor 2, Tahun 2019
Program Studi Magister Ilmu Hukum Fakultas Hukum Universitas Diponegoro
2012 lalu. Alimin menantang pemilik Hotel Meritus yang memukulinya untuk duel di Jembatan Suramadu. Merasa dianiaya, Alimin melapor ke Polisi. Alimin dilaporkan balik. Alimin pun ditahan dengan tuduhan melakukan perbuatan tidak menyenangkan karena melontarkan pernyataan menantang berkelahi. Oei Alimin Sukamto dituntut Pasal 335 ayat (1) KUHP, Pasal 406 KUHP mengenai penganiayaan dan Pasal 406 KUHP tentang penggerusakan barang yang sebagain bukan miliknya.

Dalam Pasal 21 KUHAP menjelaskan tentang kapan Tersangka atau Terdakwa dapat dilakukan penahanan termasuk delik pada Pasal 335 KUHP. Praktek ini menimbulkan kesan bahwa penahanan tujuannya tidak jelas dan sebagai ajang pemerasan oleh penegak hukum.

Mahkamah Konstitusi dalam Undang-Undang Nomor 24 Tahun 2003 tentang Mahkamah Konstitusi memiliki kewenangan sebagai pelaksana kekuasaan kehakiman (judiciary) yaitu mengadili pada tingkat pertama dan terakhir yang putusannya bersifat final.

Mahkamah Konstitusi (MK) telah menghapuskan unsur yang kontroversial dalam pasal karet yang menyebabkan ketidakpastian hukum dalam penegakan hukum pidana di Indonesia. Pasal 335 (1) Kitab Undang-Undang Hukum Pidana, melalui Putusan No. 1/PUU-XI/2013, menghapus frasa yang menjadi alasan untuk memperkarakan seseorang. Dalam pertimbangannya, Mahkamah Konstitusi menyatakan bahwa frasa "Sesuatu perbuatan lain maupun perlakuan yang tak menyenangkan" dalam Pasal 335 ayat (1) tidak mempunyai kekuatan hukum mengikat dan bertentangan dengan Undang-Undang Dasar Negara Republik Indonesia Tahun 1945.

Dasar pertimbangan hakim yang menyatakan pasal 335 Ayat (1) angka 1 KUHP merupakan pasal alternatife kurang tepat, karena setelah dikeluarkannya putusan Mahkamah Konstitusi telah terjadi sebuah pergeseran makna dalam pasal tersebut, sehingga terhadap putusan hakim yang masih menggunakan frasa "perbuatan lain maupun perlakuan yang tak menyenangkan" dapat dilakukan upaya hukum (Anggraeni, 2019).

Pasal 335 ayat (1) butir 1 Undang-Undang Nomor 1 Tahun 1946 tentang Peraturan Hukum Pidana atau Kitab Undang-Undang Hukum Pidana menjadi berbunyi :

"Barang siapa secara melawan hukum memaksa orang lain supaya melakukan, tidak melakukan atau membiarkan sesuatu, dengan memakai kekerasan, atau dengan memakai ancaman kekerasan, baik terhadap orang itu sendiri maupun orang lain".

Frasa dalam Pasal 335 ayat (1) butir 1 KUHP telah menimbulkan ketidakpastian hukum dan ketidakadilan karena memberikan peluang terjadinya kesewenang-wenangan penyidik dan penuntut umum. Frasa kata "sesuatu perbuatan lain maupun perlakuan yang tak menyenangkan" pada tahun 2013 diuji materi oleh Mahkamah Konstitusi (MK). MK menyatakan bahwa frasa perbuatan tidak menyenangkan memiliki makna kabur sehingga tidak memberikan kepastian hukum kepada masyarakat. 
Jurnal Pembangunan Hukum Indonesia

Volume 1, Nomor 2, Tahun 2019
Program Studi Magister Ilmu Hukum

Fakultas Hukum Universitas Diponegoro
Akibatnya pasal tersebut dapat melahirkan kesewenang-wenangan dari penegak hukum atau seseorang dapat dengan mudah menuntut seseorang dengan dasar pasal 335 tersebut. Sehingga bertentangan dengan prinsip konstitusi yang menjamin perlindungan atas hak untuk mendapatkan kepastian hukum yang adil dalam proses penegakan hukum (Pasal 28D ayat (1) UUD 1945)

Kasus Oei Alimin yang terjadi pada tahun 2012, saat ini masih dalam proses persidangan. Persidangan perdana dilaksanakan pada tanggal 27 Mei 2015. Penerapan hukum pada putusan Mahkamah Konstitusi pada dasarnya bersifat Prospektif atau berlaku kedepan, bukan bersifat Retroaktif atau berlaku surut agar tidak terjadi penyalahgunaan delik lagi.

Putusan Mahkamah Konstitusi telah memiliki kekuatan hukum tetap sejak dibacakan oleh Hakim Konstitusi dalam persidangan. Sedangkan putusan pengadilan yang memiliki kekuatan hukum tetap, memiliki kekuatan hukum mengikat untuk dilaksanakan. Tidak ada alasan bagi petugas hukum untuk berdalih jika Putusan Mahkamah Konstitusi No. 1/PUU-XI/2013 tentang Pasal 335 ayat (1) bertentangan dengan UUD 1945 dan tidak mempunyai kekuatan mengikat, karena kewenangan dan hak Mahkamah Konstitusi selain diatur dalam Peraturan Perundang - undangan tentang Mahkamah Konstitusi juga telah diatur dalam Pasal 24c ayat (1) UUD 1945.
Dalam Putusan Mahkamah Konstitusi Nomor: 1/PUU-XI/2013 tentang Penghapusan Frasa Perbuatan Tidak Menyenangkan pada Pasal 335 KUHP, dalam hal Pendapat Mahkamah point [3.15] dan [3.16] menyatakan bahwa :

"[3.15]Menimbang bahwa terhadap isu konstitusional tersebut, menurut Mahkamah sebagai suatu rumusan delik, kualifikasi, tidak dapat diukur secara objektif. Seandainya pun dapat diukur maka ukuran tersebut sangatlah subjektif dan hanya berdasarkan atas penilaian korban, para penyidik, dan penuntut umum semata. Selain itu, hal tidak menyenangkan tersebut secara umum merupakan dampak dari semua tindak pidana. Setiap tindak pidana jelas tidak menyenangkan dan tidak ada dampak tindak pidana yang menyenangkan. Dengan demikian, hal tersebut bukan merupakan sesuatu yang dapat membedakan secara tegas (distinctive) dari tindak pidana yang lain;

[3.16] Menimbang bahwa sebagai akibat dari adanya rumusan delik yang demikian tersebut, dapat juga menjadi peluang bagi penyidik dan penuntut umum untuk berbuat sewenangwenang terhadap orang lain berdasarkan suatu laporan. Meskipun harus diakui bahwa pada akhirnya hal demikian harus dibuktikan di pengadilan, akan tetapi apabila laporan tersebut terbukti, maka hal tersebut menjadi wajar dan tidak ada kesewenang-wenangan. Sebaliknya, apabila tidak terbukti maka pihak yang dilaporkan jelas telah menderita kerugian karena harus berurusan dengan penyidik dan penuntut umum dan terlebih lagi apabila yang bersangkutan ditahan [vide Pasal 21 ayat (4) huruf $b$ KUHAP]. Dengan demikian berarti seseorang telah kehilangan kemerdekaan sebagai hak asasinya, padahal hukum pidana dan hukum acara pidana justru untuk melindungi hak asasi dari kesewenang-wenangan penegak hukum. Selain itu, yang bersangkutan secara moral dan sosial telah dirugikan karena telah mengalami stigmatisasi sebagai orang yang tercela sebagai akibat laporan tersebut." 
Jadi dasar utama dari putusan MK untuk merubah pasal 335 KUHP lewat Putusan Mahkamah Konstitusi Nomor: 1/PUU-XI/2013 adalah karena rumusan delik, kualifikasi, maupun perlakuan yang tak di ukur secara objektif. Seandainya dapat diukur, maka ukuran tersebut sangatlah subjektif dan hanya berdasarkan atas penilaian korban, para penyidik, dan penuntut umum semata. Selain itu, rumusan delik pada pasal 335 KUHP sepanjang frase maupun perlakuan, dapat menjadi celah dan peluang bagi penyidik serta penuntut umum untuk berbuat sewenang-wenang terhadap orang lain berdasarkan suatu laporan (Swadana, 2014).

\section{Delik Perbuatan Tidak Menyenangkan dalam KUHP Dimasa yang Akan Datang}

Melihat kembali perjalanan penyusunan RKUHP dan RKUHAP, telah dimulai sejak lama. RKUHP mengatur sejumlah perubahan fundamental mengenai arah pembaruan hukum pidana di Indonesia, yang berbeda dengan KUHP saat ini. RKUHP tidak memberikan pembedaan antara kejahatan dan pelanggaran. RKUHP memperkenalkan beberapa konsep baru dan juga bentuk-bentuk pemidanaan lain yang sebelumnya tidak ada di KUHP, yakni kerja sosial. RKUHP mempertahankan hukuman mati sebagai hukuman pokok yang bersifat alternatif.

Delik Perbuatan tidak menyenangkan belum diatur secara khusus dalam RKUHP ini. Perbuatan Tidak Menyenangkan yang di dalamnya terdapat beberapa perbuatan yang mengganggu ketentraman orang lain atau ketentraman umum. Beberapa perbuatan yang termasuk dalam delik Perbuatan Tidak Menyenangkan, antara lain : Bab V Tindak Pidana Terhadap Ketertiban Umum Bagian Kelima Buku II yaitu Gangguan terhadap Ketertiban dan Ketenteraman Umum Paragraf 1 (Memasuki Rumah dan Pekarangan Orang Lain) Pasal 299. Dalam pasal ini menunjukkan seseorang yang memasuki rumah, ruangan, atau pekarangan tertutup yang dipergunakan oleh orang lain atau yang sudah berada di dalamnya dengan memaksa dan tidak pergi ketika sudah disuruh pergi termasuk perbuatan tidak menyenangkan karena menggangu ketentraman orang lain, paragraf 6 (Penyiaran Berita Bohong dan Berita yang Tidak Pasti) Pasal 307, bab XIX Tindak Pidana Penghinaan, Bagian Kesatu (Pencemaran) Pasal 537, bagian Kedua (Fitnah) Pasal 538, bagian Ketiga Penghinaan Ringan Pasal 540, bab XXVI tentang Tindak Pidana Pemerasan dan Pengancaman. Pasal 609 (Pemerasan) dan bab XXVI mengenai Tindak Pidana Pemerasan dan Pengancaman, Pasal 610 (Pengancaman).

Penghinaan yang tidak bersifat penistaan atau penistaan tertulis yang dilakukan terhadap seseorang baik di muka umum dengan lisan atau tulisan, maupun di muka orang yang dihina tersebut secara lisan atau dengan perbuatan atau dengan tulisan yang dikirimkan atau diterimakan kepadanya, dipidana karena penghinaan ringan. Sebelum putusan Mahkamah Agung, Pasal 335 KUHP mengenai Perbuatan Tidak Menyenangkan juga digunakan dalam tuntutan pencemaran nama baik 
dan penghinaan sebagai suatu perbuatan yang merugikan dan menganggu kehidupan korban penghinaan dan pencemaran. Pelaku penyiaran berita bohong dan berita yang tidak pasti (Pasal 307 RKUHP) jelas sangat merugikan pihak yang bersangkutan dengan kabar tersebut. Dalam RKUHP, pencemaran, penghinaan, maupun penghinaan ringan diatur tersendiri pada Bab XIX Tindak Pidana Penghinaan, Bagian Kesatu sampai dengan Bagian Ketiga. Ketentuan pidana sudah diatur dalam masing - masing pasal. Sebagai tambahan ketentuan pidana pada Pasal 537 sampai dengan Pasal 540, dapat ditambah dengan 1/3 (satu per tiga), jika yang dihina atau difitnah adalah seorang pegawai negeri yang sedang menjalankan tugasnya yang sah.

Tidak adanya delik Perbuatan Tidak Menyenangkan dalam RKUHP di masa mendatang dimaksutkan agar tidak terjadi lagi kerancuan dalam penjatuhan pidana. Sebagai gantinya, RKUHP mengatur tentang delik - delik yang dapat menjadi kerancuan delik.

Pengaturan Penegakan Hukum Tindak Pidana Perbuatan Tidak Menyenangkan Sebelum Penghapusan Frasa "Perbuatan Tidak Menyenangkan" Dalam Pasal 335 Kitab Undang Undang Hukum Pidana (KUHP) Oleh Mahkamah Konstitusi Penegakan Hukum mempunyai hubungan yang erat antara kehidupan hukum suatu bangsa dengan Analisis Penghapusan Frasa Perbuatan (Tuhumury, 2015). Susunan atau tingkat perkembangan sosial bangsa itu sendiri, karena tidak setiap bangsa atau Negara serta masyarakat mempunyai kebutuhan yang sama dalam kehidupan hukumnya. Demikianlah pada saat kita membicarakan masyarakat yang tergolong sederhana sekali, terlihat di situ betapa sederhananya pula dari kebutuhan masyarakat itu mengenai penyelenggaraan hukumnya. Penyelenggaraan yang sederhana itu juga mengakibatkan bahwa badan-badan yang belum begitu banyak dan rumit tata kerjanya. Penggunaan upaya hukum, termasuk hukum pidana sebagai salah satu upaya untuk mengatasi masalah social termasuk dalam bidang kebijakan sosial, yaitu segala usaha yang rasional untuk mencapai kesejahteraan masyarakat sebagai suatu masalah yang termasuk masalah kebijakan, maka penggunaan (hukum) pidana sebenarnya tidak merupakan suatu keharusan.

$$
\text { Rumusan Pasal } 335 \text { ayat (1) KUHP }
$$
mensyaratkan adanya pemenuhan atas dua unsur yakni "memakai kekerasan" atau "ancaman kekerasan. Melihat rumusan bagian inti delik (delicts bestanddelen), maka kita dapat melihat bahwa tindak pidana tersebut berupa : Pelaku (barang siapa), bentuk perbuatannya adalah memaksa, menyuruh orang untuk melakukan/ tidak melakukan sesuatu, sehingga orang itu melakukan/atau tidak melakukan sesuatu yang berlawanan dengan kehendaknya, objeknya adalah orang, dilakukan secara melawan hukum. 
Jurnal Pembangunan Hukum Indonesia

Volume 1, Nomor 2, Tahun 2019
Program Studi Magister Ilmu Hukum Fakultas Hukum Universitas Diponegoro

\section{SIMPULAN}

Berdasarkan uraian hasil penelitian dan analisis, dalam skripsi ini dapat ditarik beberapa simpulan, sebagai berikut : Kebijakan hukum pidana mengenai delik perbuatan tidak menyenangkan saat ini telah diatur dalam Pasal 335 KUHP. Namun, pasal tersebut oleh Mahkamah Konstitusi berdasarkan putusan Nomor 1/PUU-XI/2013, frasa "sesuatu perbuatan lain maupun perlakuan yang tidak menyenangkan" dihilangkan karena dianggap multi tafsir.

Kebijakan hukum pidana terhadap perbuatan yang tidak menyenangkan di masa mendatang belum diatur secara khusus dalam RUU KUHP. Terdapat delik - delik yang mengandung unsur - unsur Pasal 335 KUHP dalam rumusan RKUHP, antara lain : Memasuki Rumah dan Pekarangan Orang Lain (Pasal 299), Penyiaran Berita Bohong dan Berita yang Tidak Pasti (Pasal 307), Tindak Pidana Penghinaan (Pencemaran : Pasal 537, Fitnah Pasal : 538, Penghinaan Ringan : Pasal 540), Tindak Pidana Pemerasan (Pasal 609) dan Pengancaman (Pasal 610). Isi pasal - pasal RKUHP Buku Kedua ini terdapat unsur yang memenuhi delik Perbuatan Tidak Menyenangkan yaitu memaksa, memakai kekerasan, dan adanya ancaman kekerasan.

\section{DAFTAR PUSTAKA}

\section{BUKU}

Arief, Barda N. (2005). Bunga Rampai Kebijakan Hukum Pidana.Cet III. Bandung: PT. Citra Bakti.
Hamzah, A. (2008) Asas -asas Hukum Pidana. Jakarta: Rineka Cipta.

Soeharto. (1991). Hukum Pidana Materiil. Jakarta: Sinar Grafika.

Prodjodikoro, W. (1981). Asas-Asas Hukum Pidana di Indonesia. Jakarta: Eresco

\section{TESIS}

Aulia, K. (2018), Pertanggungjawaban Pidana Kepada Para Pelaku Tindakan Persekusi Dalam Perspektif Hukum Pidana. Tesis, Fakultas Hukum Universitas Pasundan.

Swadana, Dimas I. (2014). Implikasi Yuridis Dari Perubahan Pasal 335 Kuhp Ayat (1) Butir Ke-1 Tentang Perbuatan Tidak Menyenangkan Oleh Mahkamah Konstitusi Berdasarkan Putusan Nomor: 1/Puu-Xi/2013 Tentang Penghapusan Frase Perbuatan Yang Tidak Menyenangkan. Artikel Ilmiah, Fakultas Hukum Universitas Brawijaya.

\section{J URNAL}

Anggraeni, N. (2019). Analisis Putusan Hakim Nomor 607/Pid.B/2015/Pn.Kag Pasca Putusan Mahkamah Konstitusi Nomor 1/Puu-Xi/2013 Tentang Perbuatan Tidak Menyenangkan Pasal 335 Ayat (1) Angka 1 Kitab UndangUndang Hukum Pidana. Jurnal Hukum, Sarjana IImu Hukum, Februari 2019. Fakultas Hukum Universitas Brawijaya.

Cogan, Jeanne C. (2002). Hate Crime as a Crime Category Worthy of Policy Attention. American 
Jurnal Pembangunan Hukum Indonesia

Volume 1, Nomor 2, Tahun 2019
Program Studi Magister Ilmu Hukum Fakultas Hukum Universitas Diponegoro

Behavioral Scientist, Vol.46,(No.1), pp. 173- Tuhumury, Harry A. (2015). Analisis Penghapusan 185.

Frasa Perbuatan Tidak Menyenangkan Dalam

Natamenggala, Muhammad Alriezki., Raharjo, Eko., Pasal 335 Kitab Undang Undang Hukum \& Gustiniati, Diah. (2018). Implementasi Pidana (KUHP) Oleh Mahkamah Konstitusi. Putusan Mahkamah Konstitusi Nomor: 1/PuuJ urnal Hukum "Legal Pluralism", Vol 5, (No 2), Xi/2013 Tentang Frasa Perbuatan Tidak pp. 1.

Menyenangkan. J urnal Poenale, Vol 6, (No 4), pp.3.

Kantjai, Marcelly M. (2016). Pasal 335 Ayat (1) Ke-1 Kitab Undang-undang Hukum Pidana Dari Aspek Lex Certa Pada Asas Legalitas. Lex Crimen, Vol 5, (No 1), pp. 31

Haider-Markel, Donald P. (1998). The Politics of Social Regulatory Policy: State and Federal Hate Crime Policy and Implementation Effort. Political Research Quarterly, Vol.51,(No.1), pp.69-88.

Swadana, Dimas Indra., Triyoso, Paham., \& Istiqomah, Milda. (2014). Implikasi Yuridis Dari Perubahan Pasal 335 Kuhp Ayat (1) Butir Ke-1 Tentang Perbuatan Tidak Menyenangkan Oleh Mahkamah Konstitusi Berdasarkan Putusan Nomor: 1/PUU-XI/2013 Tentang Penghapusan Frase Perbuatan Yang Tidak Menyenangkan. J urnal Hukum, Sarjana IImu Hukum, Agustus 2014.Fakultas Hukum Universitas Brawijaya. 